第 28 回年次大会予稿

\title{
戦後の歴代首相の施政方針演説と所信表明演説の計量分析 Quantitative Analysis of Post-War Japanese Prime Ministers' Diet Speeches
}

河瀬 彰宏 ${ }^{\dagger *}$, 吉原秀樹 $\dagger$

\author{
Akihiro KAWASE ${ }^{\dagger *}$, Hideki YOSHIHARA ${ }^{\dagger}$
}

$\dagger$ 同志社大学文化情報学部

Faculty of Culture and Information Science, Doshisha University

干 610-0394 京都府京田辺市多々羅都谷 1-3

E-Mail: akawase@mail.doshisha.ac.jp

* 連絡先著者 Corresponding Author

本研究では，戦後日本の首相の国会演説（施政方針演説・所信表明演説）に対してテキスト分析を行い, その内容の通時的変化を明らかにした。 1945 年の東久邇宮内閣から 2019 年の第四次安倍内閣までの全 179 本の演説を収集し, 昭和前期, 昭和後期, 平成前期, 平成後期の 4 時代に区分した上で, 頻出名詞に対して TF-IDF 值を算出した。そして，全演説に対して LDA によるトピックモデルを作成し，首相ごとのトピッ クの推定を実施した.

In this study, we conducted text mining on the Diet speeches (both administrative policy speech and prime minister's general policy speech) of post-war Japanese prime ministers to clarify the chronological changes in political thoughts. A total of 179 speeches from the Higashikuni-no-miya Cabinet (1945) to the fourth Abe Cabinet (2019) were collected, and morphological analysis was performed after dividing them into four periods: the first half and latter half of the Showa era, and the first half and latter half of the Heisei era. Characteristic words were extracted by calculating TF-IDF values for frequent nouns in each era. Then, a topic model using LDA was created for all speeches, and topics were estimated for each prime minister.

キーワード： 国会演説，政治思想，テキスト分析，LDA

Diet speeches, political thoughts, text analysis, LDA

\section{1 はじめに}

小泉政権の誕生以降，日本の政治家の話し方が変 化している. 東（2006）によれば, 政治学者とマス コミは，小泉純一郎が就任した 2001 年以降の小泉 首相の演説様式を「ワンフレーズ・ポリティクス」 と呼称した [1]. 瀬良 (2009) は, このワンフレーズ・ ポリティクスが言葉の繰り返しによって聴衆に影響 を与え, 演説者自身の意志を反映させる効果をもつ と考察している [2]. 第 95 代内閣総理大臣の野田佳 彦の演説は, 比喻表現を多用した演説が高い評価に 繋がっていたという指摘もされている [3].

従来より, 演説に対するテキスト分析によって演 説者の思想を明らかにする試みが多くなされており， 自然言語処理技術の利便性が向上したことにより，
精緻な分析も実現しつつある.

これまでに政治テキストに対する統計的分析は数 多く実施されてきた。東（2006）は, 東条英機から 小泉純一郎までの所信表明演説と国会答弁の発言に ついて, 発話内容の総字数, 文節数, 文末表現, 頻 出語彙を時系列データとして表現・比較した。その 結果, 文末表現「〜あります」や動詞の名詞化「〜こ と」の使用率が時代の経過とともに減少しているこ とから, 首相の演説は聴衆を意識した内容に変化し ていることを明らかにした [1]. 村井ら（2008）は， 2006 年 12 月から 2007 年 5 月に Web サイトを開設 している 646 名の議員のテキストに対して形態素解 析を実施し,『分類語彙表』を用いて形容詞の頻出 上位語をカテゴリ分類・比較した。 その結果, 政党 間で用いられる感性語に差異があること, 議員の所 
属が自民党 $\succ$ 民主党 $\succ$ 共産党 社民党の順にポジ ティヴな語彙が多用されることを明らかにした [4].

鈴木・影浦（2011）は，データベース「世界と日 本」[6]における第二次世界大戦後の歴代首相 27 人 28 期が行った計 150 本の国会演説（施政方針演説 と所信表明演説）に対して, 時代ごとに名詞の使用 頻度, 語彙の多様性と偏差を比較した。その結果, 日本政治において強いリーダーシップを発揮したと 報道されている中曽根康弘と小泉純一郎の特徵を各 種語彙の統計量を用いて明確に裏付けた [5].

このように, 政治家の演説に対するテキスト分析 は, 政治的解釈に有効であること, 首相の使用語彙 は時代ごとに変化していること, 首相の演説の変化 には，社会的な要因が存在すること，などが明らか にされてきた。首相の国会演説の内容は, 経済・外 交・行政など多岐に及びものの，その射程は概ね決 められていることから, 演説に現れる政治思想につ いても社会的な要因が関係していると考えられる.

そこで, 本研究では, 戦後日本の首相の国会演説 に着目し，その演説から政治トピックを推定するこ とで，政治思想の遷移を明らかにすることを目的と した。

\section{2 分析方法}

\section{1 分析データの概要}

本研究では，データベース「世界と日本」[6]に 記録された歴代首相の施政方針演説と所信表明演説 のうち, 東久邇宮内閣以降の全演説を収集した。

表 4 は, 本研究に用いた全 33 名の首相の氏名, 就 任年月, 演説本数, 後述する語彙の豊富さに関する 指標を就任年月順に並べた表である. ただし，*を 付与した吉田茂と安倍晋三については, 2 回の就任 のうち演説本数の多かった時期に配置した。 また, 次の社会情勢の変化に基づき時代区分を設けた：I. 東久邇宮稔彦から安保闘争が終了した岸信介までの 内閣を昭和前期 ; II. 池田勇人からバブル経済の発 生と日経平均株価の最高值を更新した竹下登までの 内閣を昭和後期 ; III. 宇野宗佑から自民党が公明党 との連立政権に至った小㴊恵三までの内閣を平成前 期 ; IV. それ以降の森喜朗から安倍晋三までの内閣 を平成後期.

\section{2 形態素解析}

本研究における形態素解析は, 解析器に MeCab, 解析辞書に現代話し言葉 UniDic を用いて, Python 3.6 .5 で記述したスクリプトで実施し, 名詞のみを 抽出した。抽出した名詞について誤って判定された 名詞 (句), 接頭辞, 接尾辞を解析対象から除外し た上で再解析を実施した。単語リストの選定につい ては, 解析器の ChaSen を用いて複合語を検出し, Zipf の法則における「中程度の頻度」を索引語とし て採用した Maron（1961）[7]に基づき, 出現回数 7 回以上の語彙を解析辞書に登録した.

本研究では, 語彙の重要度を測る指標として各名 詞の TF-IDF 值を算出した。 TF 值は, ある文書 $d$ に存在する単語 $t$ の出現回数 $n_{t, d}$ を全単語の総出現 回数 $\sum_{s \in d} n_{s, d}$ で割った值として定義する. IDF 值 は, 対象とする全文書数 $U$ を単語 $t$ が出現する文書 数 $d f(t)$ で割り, 対数をとった值として定義する：

$$
\mathrm{TF}=\frac{n_{t, d}}{\sum_{s \in d} n_{s, d}}, \quad \mathrm{IDF}=\log \frac{U}{d f(t)+1} .
$$

ここでは首相ごとの演説と時代区分をそれぞれ $d$ と して設定した場合の TF-IDF 值を算出し, 首相間で の重要度の高い語彙と時代区分での重要度の高い語 彙を比較した。

\section{3 トピックモデル}

トピックモデルとは, 文書の内容が複数の話題 (ト ピック）から構成されるものと仮定して, 確率モデ ルを用いて単語の出現頻度から文書ごとのトピック とその割合を推定する方法である．代表的な手法 として, 本研究では, 学習データに依存せず文書 内トピックの推定が行える LDA（Latent Dirichlet Allocation）を用いてモデルを構築した. トピック モデルでは, 抽出するトピック数は任意に設定でき るが，ここでは客観性を担保するために，モデルの 性能を評価する Perplexity と Coherence の 2 つの 指標を用いてトピック数を決定した. Perplexity に ついては, 文書数 $d$, 出現した単語数 $N$, 周辺の単 語に対するある単語 $w_{i}$ の発生確率を $P\left(w_{i} \mid d\right)$ と するとき, 次式で定義される指標 $P P L$ を用いた：

$$
P P L=\exp \left\{-\frac{1}{N} \sum_{i=1}^{N} \log _{2} P\left(w_{i} \mid d\right)\right\} .
$$


Coherence については, 自然言語処理モジュール Gensim [10] における定義のうち, 最も精度が高い とされている引数 $C_{v}$ を用いた. Perplexity の值が 小さいほど，そのトピック数を用いて構築したモデ ルの性能が優れていると評価でき, Coherence の值 が大きいほど，そのトピック数を用いて構築したモ デルの性能が優れていると評価できる.さらに, こ の 2 つの指標を用いる妥当性を示すために, 採用し た各トピックが属する文書の割合とトピック間の距 離を多次元尺度構成法（MDS）で表した（図 1）。

\section{3 分析結果}

\section{1 語彙の豊富さ}

表 1 は，時代区分ごとに算出した TF-IDF 值の 上位 20 位の頻出名詞の結果である. いずれの時代 についても「国」「国民」「経済」が上位に位置して いることが読み取れる．昭和前期に「平和」「努力」 「安定」といった名詞が上位に位置しているが，時 代が下るにつれてその順位を落としている．また， 昭和前期では「民主」「主義」が 12 位と 13 位に位置 していることに対して，昭和後期以降には登場しな い，その一方で，平成前期と平成後期において「改 革」がそれぞれ 4 位と 3 位に位置していることに対 して, 昭和前期と昭和後期の上位 20 位以内には出 現していない. 同様に，平成前期と平成後期には， 「地域」が 14 位と 11 位に位置していることに対し て，それ以前の時代では上位 20 位以内に位置しな い，また，昭和前期には「諸君」が 19 位に出現し， 昭和前期と昭和後期には, 「平和」「努力」「安定」と いった形容詞的名詞が上位に出現した。

\section{2 トピックモデル}

図 1 は，全演説を対象にしたモデルに対してト ピック数ごとの Perplexity と Coherence の值を比 較した結果である。ここでは, 各トピックの解秎を 明確に行えるように 9 つのトピックを採用した。表 2 は，全演説から構築したトピックモデルにおける， 出現率上位 10 位の名詞の一覧である. 表中の 1 行目 は, 各トピックに出現する名詞から命名したトピッ ク名である．以上の 9 トピックに基づき，歴代の各 首相の演説における使用語彙の割合を図 2 に, 時代 ごとの各トピックの出現率の平均值を表 3 に示す.
表 1: 時代区分ごとの TF-IDF 值 (上位 20 位)

\begin{tabular}{|c|c|c|c|c|c|c|c|c|}
\hline & \multicolumn{2}{|c|}{ 昭和前期 } & \multicolumn{2}{|c|}{ 昭和後期 } & \multicolumn{2}{|c|}{ 平成前期 } & \multicolumn{2}{|c|}{ 平成後期 } \\
\hline 順位 & 名詞 & TF-IDF & 名詞 & TF-IDF & 名詞 & TF-IDF & 名詞 & TF-IDF \\
\hline 1 & 国民 & 0.362 & 国 & 0.305 & 国 & 0.323 & 日本 & 0.257 \\
\hline 2 & 政府 & 0.332 & 経済 & 0.289 & 社会 & 0.275 & 社会 & 0.232 \\
\hline 3 & 経済 & 0.257 & 国民 & 0.279 & 経済 & 0.263 & 改革 & 0.230 \\
\hline 4 & 国 & 0.248 & 社会 & 0.203 & 改革 & 0.226 & 国 & 0.215 \\
\hline 5 & 平和 & 0.149 & 国際 & 0.195 & 国民 & 0.215 & 国民 & 0.213 \\
\hline 6 & 世界 & 0.127 & 政府 & 0.185 & 政治 & 0.185 & - & 0.204 \\
\hline 7 & 国際 & 0.123 & 関係 & 0.175 & 国際 & 0.178 & 経済 & 0.201 \\
\hline 8 & 日本 & 0.122 & 問題 & 0.165 & - & 0.149 & 世界 & 0.175 \\
\hline 9 & 努力 & 0.120 & 世界 & 0.163 & 関係 & 0.148 & 年 & 0.136 \\
\hline 10 & - & 0.119 & 努力 & 0.150 & 問題 & 0.147 & 二 & 0.130 \\
\hline 11 & 安定 & 0.115 & - & 0.149 & 世界 & 0.146 & 地域 & 0.120 \\
\hline 12 & 民主 & 0.114 & 平和 & 0.142 & 協力 & 0.125 & 皆 & 0.117 \\
\hline 13 & 主義 & 0.108 & 安定 & 0.139 & 平和 & 0.122 & 実現 & 0.115 \\
\hline 14 & 問題 & 0.104 & 協力 & 0.133 & 地域 & 0.119 & 制度 & 0.107 \\
\hline 15 & 国家 & 0.101 & 日本 & 0.112 & 推進 & 0.115 & 支援 & 0.104 \\
\hline 16 & 生産 & 0.100 & 政治 & 0.108 & 努力 & 0.114 & 三 & 0.101 \\
\hline 17 & 協力 & 0.099 & 発展 & 0.101 & 実現 & 0.106 & 関係 & 0.092 \\
\hline 18 & 国会 & 0.099 & 推進 & 0.095 & 生活 & 0.095 & 問題 & 0.091 \\
\hline 19 & 諸君 & 0.096 & 生活 & 0.086 & 行政 & 0.095 & 地方 & 0.090 \\
\hline 20 & 産業 & 0.096 & 今後 & 0.086 & 環境 & 0.093 & 国際 & 0.090 \\
\hline
\end{tabular}

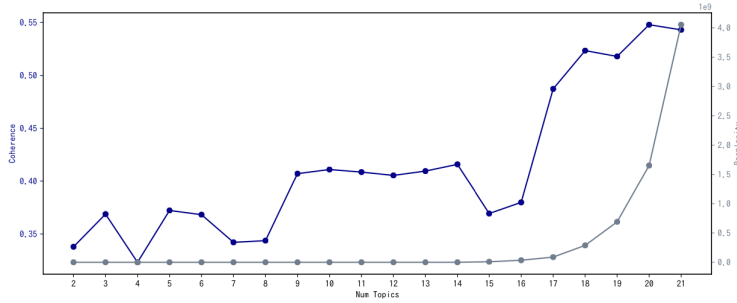

図 1:トピック数ごとの Perplexity と Coherence

表 3 より，全時代に渡って首相が国会演説におい て言及するトピックは，2，5，7，4，9 の順に高い ことがわかった。

図 3 は，9つのトピック間の距離を MDS によっ て平面上に配置した結果である. 円の中心に付記さ れた数值は表 2 のトピック番号と対応しており, 円 の半径は各トピックに所属する文書数の合計（演説 数）に正比例している．いずれのトピックも重なり がなく, 各トピックが適切に分離しており, 特に, トピック 1 は，3，4，8 と近い話題であることがわ かった。

\section{4 考察}

各時代区分によりトピックの遷移が存在し，その 特徵語彙に変化があったことが明らかになった。昭 和前期では,「平和」「努力」「安定」といった語彙や， 「諸君」といった二人称の単語が上位に位置してい た。これらは，第二次世界大戦後に首相が，国民や 国会議員に対して戦後復興へ向けた奮起を及ぼそう 
情報知識学会誌 2020 Vol. 30, No. 2

表 2: 9 トピックに所属する上位語（上位 10 位）

\begin{tabular}{|c|c|c|c|c|c|c|c|c|c|c|c|c|c|c|c|c|c|c|}
\hline & \multicolumn{2}{|c|}{ "1: 国家制度 } & \multicolumn{2}{|c|}{ "2: 国内情勢 } & \multicolumn{2}{|c|}{ "3: 執政内容 } & \multicolumn{2}{|c|}{ 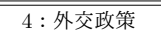 } & \multicolumn{2}{|c|}{ "5: 地方創生 } & \multicolumn{2}{|c|}{ "6:教育研究 } & \multicolumn{2}{|c|}{ "7 : 労働環境 } & \multicolumn{2}{|c|}{ "8:インフラ } & \multicolumn{2}{|c|}{ "9: 国家予算 } \\
\hline 順位 & 名詞 & 出現率 & 名詞 & 出現率 & 名詞 & 出現率 & 名詞 & 出現率 & 名詞 & 出現率 & 名詞 & 出現率 & 名詞 & 出現率 & 名詞 & 出現率 & 名詞 & 出現率 \\
\hline 1 & 警察 & 0.087 & 社会 & 0.083 & 行政 & 0.110 & 経済 & 0.207 & 国 & 0.109 & 教育 & 0.18 & 労働 & 0.072 & 政治 & 0.099 & 予算 & 0.073 \\
\hline 2 & 改革 & 0.060 & 基本 & 0.058 & 年 & 0.041 & 協力 & 0.022 & 地方 & 0.095 & 日本 & 0.122 & 対策 & 0.055 & 防衛 & 0.044 & 関係 & 0.059 \\
\hline 3 & 制度 & 0.044 & 問題 & 0.042 & 住宅 & 0.034 & アジア & 0.012 & 平和 & 0.044 & エネルギー & 0.017 & - & 0.034 & 整備 & 0.014 & 円 & 0.033 \\
\hline 4 & 国家 & 0.008 & 国民 & 0.041 & 内閣 & 0.019 & 安定 & 0.011 & 税 & 0.035 & 開発 & 0.016 & 企業 & 0.026 & 医療 & 0.014 & 0 & 0.032 \\
\hline 5 & 産業 & 0.005 & 地域 & 0.032 & 核 & 0.013 & 計画 & 0.01 & 世界 & 0.023 & 文化 & 0.011 & 雇用 & 0.023 & 民主 & 0.006 & 財政 & 0.029 \\
\hline 6 & 法 & 0.004 & 年金 & 0.030 & 九 & 0.006 & 日米 & 0.002 & 金融 & 0.016 & 施設 & 0.01 & 失業 & 0.021 & 面 & 0.005 & 年度 & 0.026 \\
\hline 7 & 時間 & 0.003 & 保障 & 0.016 & 機構 & 0.002 & 積極 & 0.001 & 規制 & 0.012 & 技術 & 0.009 & 安全 & 0.019 & 活動 & 0.004 & 二 & 0.017 \\
\hline 8 & 再生 & 0.003 & 政府 & 0.015 & 六十 & 0.001 & 支援 & 0.001 & 所得 & 0.009 & 保険 & 0.008 & 事業 & 0.016 & 決定 & 0.001 & 補正 & 0.014 \\
\hline 9 & 税制 & 0.002 & 情報 & 0.008 & 兵器 & 0.001 & 五 & 0.001 & 民間 & 0.007 & 研究 & 0.007 & 石油 & 0.014 & 閣議 & 0.001 & 億 & 0.011 \\
\hline 10 & 案 & 0.001 & 大量 & 0.006 & 実績 & 0.001 & 力年 & 0.001 & 分離 & 0.006 & 科学 & 0.005 & 国連 & 0.008 & 議会 & 0.001 & 日米 & 0.010 \\
\hline
\end{tabular}

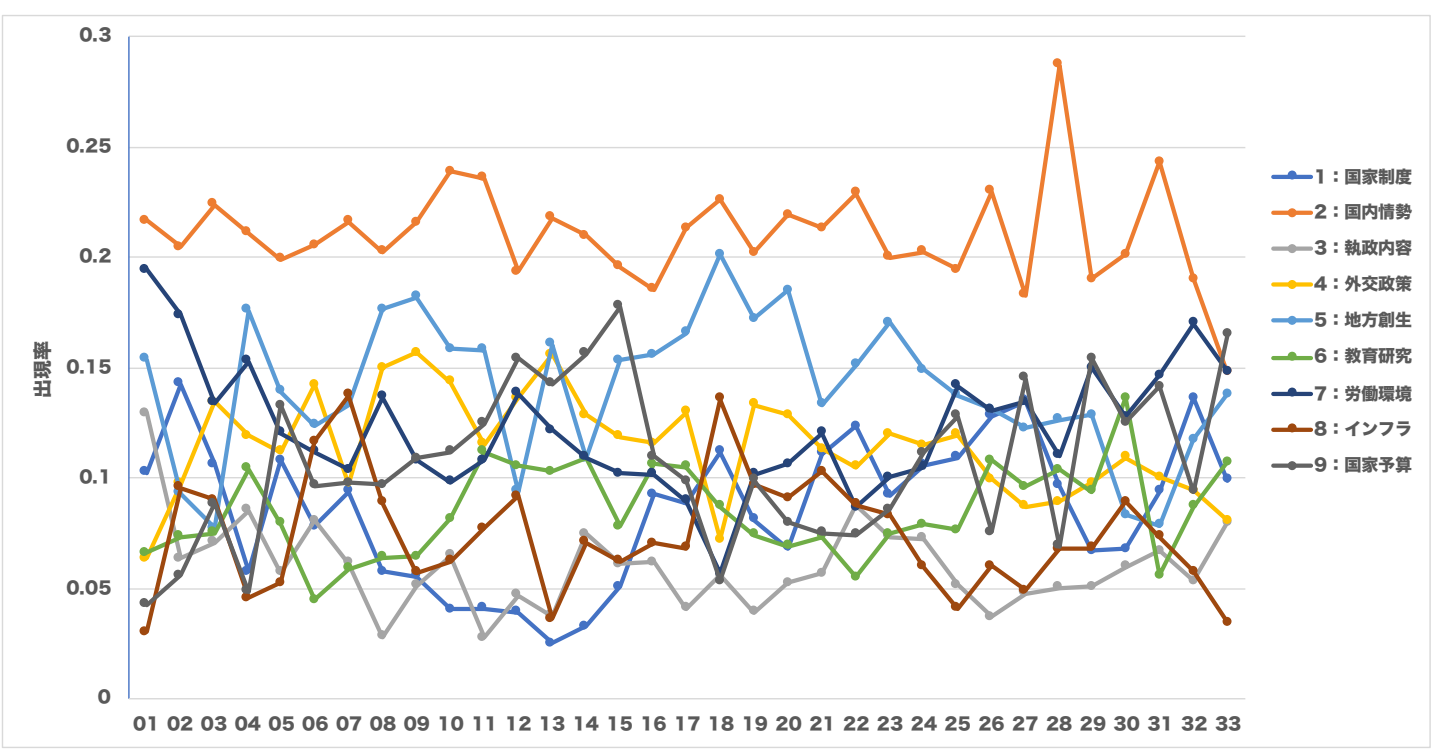

図 2: トピックの推移

表 3: 時代ごとのトピックの平均出現率

\begin{tabular}{crrrrrrrrr}
\hline \hline トピック & 1 & 2 & 3 & 4 & 5 & 6 & 7 & 8 & 9 \\
\hline 昭和前期 & 0.093 & 0.210 & 0.072 & 0.114 & 0.134 & 0.071 & 0.141 & 0.082 & 0.091 \\
昭和後期 & 0.052 & 0.212 & 0.052 & 0.133 & 0.149 & 0.096 & 0.109 & 0.066 & 0.132 \\
平成前期 & 0.100 & 0.211 & 0.061 & 0.113 & 0.162 & 0.074 & 0.102 & 0.087 & 0.088 \\
平成後期 & 0.103 & 0.209 & 0.056 & 0.095 & 0.116 & 0.098 & 0.140 & 0.062 & 0.121 \\
\hline 全時代 & 0.086 & 0.210 & 0.060 & 0.115 & 0.140 & 0.085 & 0.122 & 0.074 & 0.107 \\
\hline
\end{tabular}

としたからだと考えられる，図 2 からは，「国家制 度」「執政内容」「労㗢環境」が，他の時代よりも大 きな值を示した。これは，地方重視よりも国家の機 能を回復させようとしたからだと考えられる. 以上 から, 昭和前期の演説は, 国内の制度の整備や行政 機関の正常な運営, 国民の労働環境の整備などを重 要視し, マクロな視点で国家の回復を促そうとして いることが明らかになった。

昭和後期では，前期よりも「平和」「努力」「安定」
の順位が下がっていた。戦後復興から高度経済成長 期へと遷移する時期であったので，前期よりも抽象 的でない具体的な語彙の使用に変化があったと考え られる. 図 2 と表 3 からは,「外交政策」が全時代区 分と比べて昭和後期から最も大きな出現率を示し, 「国家予算」も同様に最も大きな出現率を示した。こ れは, 高度経済成長期に向けた財政の運用や経済に 対する関心が高かったからだと考えられる。また， 表 3 より,「教育研究」が前期よりも増加していた。 これは, 1968 年にアメリカで開催された「世界教育 危機会議」から日本を含めた世界各国で教育への関 心が高まったからだと考えられる. 以上から, 昭和 後期の演説は, 前期の国家制度の整備のマクロな視 点を継承しつつも, 高度経済成長期に向けて経済に 関するトピックへ遷移していることが明らかになっ た。それに伴い，対外諸国に関する語彙の増加も現 れ，国家の整備が段々と重要視されなくなっていっ 


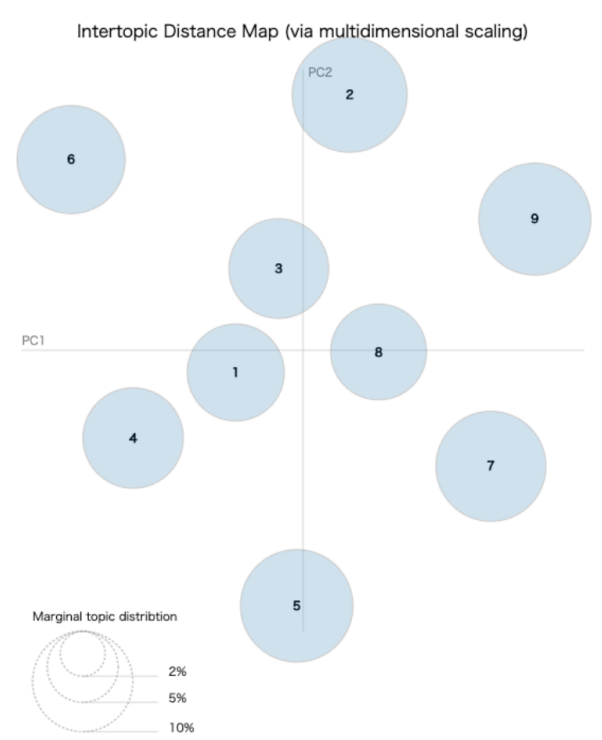

困 3: トピック間の距離の可視化

たことが明らかになった。

平成前期では, 表 1 によると, 昭和期と比べて 「改革」が上位に位置した。これは，平成後期にも 上位 20 位に位置しており，前期から既存の体制を 変革させるトピックが多く表れたと考えられる．実 際に図 1 から「国家制度」のトピックに増加が確認 できる。「国家制度」は昭和前期で増加したものの, 昭和後期で減少していた。これは, 平成前期に特徵 語として「改革」が表れたように，戦前復興で施し た制度が時代を経て旧世代のものとなり, 制度を新 しいものに変革しようとしたと表れと考えられる. 特に平成前期はバブル経済崩壊の影響を強く受けた 時代であり，その回復を促そうとして表れたとも考 えられる。 また，表 1 によと，「地域」が上位 20 位に位置した。これは, 図 1 と表 3 からもわかるよ うに,「地方創生」の出現率が増加していることと関 連している. 昭和前期に重視されていた，国家やマ クロな国内制度に関するトピックが，平成前期にか けて，ミクロな視点に遷移してきたと考えられる. 以上から, 平成前期の演説は, 昭和前期で整備した 制度を旧世代と認識し，それらを新しい時代のもの へと変化させようとしたことが明らかになった。ま た, 地方に関する特徵語彙の出現からも, 時代の変 遷ごとに具体性を帯びたトピックが重視される傾向 があることが明らかになった。

平成後期では, 表 2 によと, 前期と同じく「改 革」が上位に位置していた。また, 眓 1 と表 3 から 「国家制度」が全時代区分の平均出現率において最
大值を示していた。これは，旧時代の制度を新しく 作り変えようとした新時代的なトピックへの遷移が 表れたと考えられる. また,「教育研究」のトピック が全時代区分で最大值を示しており，特に鳩山由紀 夫（首相 ID:30）で最大值を示した。これは，近年 問題視されている少子化対策が教育に関するトピッ クの増加を起因したと考えられる。一方で,「地方創 生」は全時代区分で平均出現率が最小值を示し, 首 相鳩山由紀夫（首相 ID:30）と菅直人（首相 ID:31） において小さな值を示した。これは, 近年問題視さ れている人口の東京一極集中と関連があると考えら れる. 以上から, 平成後期の演説は, 前期と同じく 現状打破に関連した特徵語彙の出現や国家制度に関 連したトピックの増加から, 新時代への変革を施そ うとする傾向が明らかになった。

\section{5 結論}

本研究では, 戦後の歴代首相の国会演説から政治 トピックを計量し, 特徵語彙の抽出とトピックモデ ルによる演説トピックの推量を行った。 その結果, 各時代区分で政治思想の変化がみられ, 戦後から現 在にかけて国家制度の整備, 経済の発展, 国家制度 の再建と遷移していることが明らかになった。

本研究では, 時代区分を任意で設定したが, 社会 情勢との関連性をより詳細に明らかにするためには, 異なる観点からの時代区分を適用することが求めら れる. 例えば, 本研究では経済に関するトピックと 政治思想の変遷には大きな関連が見られたが，その 場合, 経済史の観点から制定された時代区分を適用 することで, 政治思想の変遷の明確な時期を明らか にできる可能性がある.

\section{参考文献}

[1] 東照二: 歴代首相の言語力を診断する, 研究社, 2006.

[2] 瀬良晴子:「小泉元首相の言葉一ワンフレーズ・ ポリティックスと演説一」, 人文論集, Vol. 44, No.1, pp. 99-112, 2009.

[3] 東照二:「どじょう宰相の言語力を診断す る」, 中央公論. http://www. chuko.co. jp/chuokoron/2011/10/post_106_1.html (2020 年 4 月 10 日参照). 
表 4: 首相の時代区分と演説本数の一覧

\begin{tabular}{|c|c|c|c|c|c|c|c|c|}
\hline 区分 & ID & 民名 & 就任年月 & 演説数 & 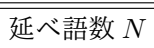 & 異なり語数 $V$ & TTR & 修正 TTR \\
\hline \multirow{8}{*}{ I. 昭和前期 } & 01 & 東久邇宮 稔彦 & 1945.08. & 1 & 5,831 & 1,458 & 0.250 & 13.501 \\
\hline & 02 & 幣原 喜重郎 & 1945.10 & 1 & 3,036 & 944 & 0.311 & 12.115 \\
\hline & 03 & 片山 哲 & 1947.05 & 5 & 9,570 & 1,555 & 0.162 & 11.240 \\
\hline & 04 & 芦田 均 & 1948.03 & 1 & 3,712 & 921 & 0.248 & 10.689 \\
\hline & 05 & 吉田 茂＊ & 1948.10 & 19 & 34,056 & 3,299 & 0.097 & 12.641 \\
\hline & 06 & 鳩山一郎 & 1954.12 & 5 & 8,884 & 1,451 & 0.163 & 10.885 \\
\hline & 07 & 石橋 湛山 & 1956.12 & 1 & 2,850 & 791 & 0.278 & 10.477 \\
\hline & 08 & 岸信介 & 1957.02. & 9 & 19,189 & 2,260 & 0.118 & 11.536 \\
\hline \multirow{9}{*}{ II. 昭和後期 } & 09 & 池田 勇人 & 1960.12 & 11 & 37,360 & 3,165 & 0.085 & 11.579 \\
\hline & 10 & 佐藤 栄作 & 1964.11 & 21 & 59,923 & 3,739 & 0.062 & 10.800 \\
\hline & 11 & 田中 角栄 & 1972.06 & 4 & 15,914 & 2,115 & 0.133 & 11.855 \\
\hline & 12 & 三木 武夫 & 1974.12 & 5 & 19,174 & 2,481 & 0.129 & 12.669 \\
\hline & 13 & 福田 趃夫 & 1976.12 & 5 & 17,939 & 2,074 & 0.116 & 10.950 \\
\hline & 14 & 大平 正芳 & 1978.12 & 4 & 16,670 & 1,985 & 0.119 & 10.871 \\
\hline & 15 & 鈴木 善幸 & 1980.06 & 4 & 14,608 & 1,752 & 0.120 & 10.250 \\
\hline & 16 & 中曽根 康弘 & 1982.11 & 10 & 50,356 & 3,415 & 0.068 & 10.761 \\
\hline & 17 & 竹下 登 & 1987.11. & 4 & 19,575 & 2,047 & 0.105 & 10.346 \\
\hline \multirow{8}{*}{ III. 平成前期 } & 18 & 宇野 宗佑 & 1989.06. & 1 & 3,921 & 957 & 0.244 & 10.807 \\
\hline & 19 & 海部 俊樹 & 1989.08 & 5 & 24,696 & 2,526 & 0.102 & 11.366 \\
\hline & 20 & 宮澤 喜一 & 1991,11 & 4 & 20,347 & 2,165 & 0.106 & 10.732 \\
\hline & 21 & 細川 護熙 & 1993.08 & 3 & 15,537 & 2,070 & 0.133 & 11.743 \\
\hline & 22 & 羽田 孜 & 1994.04. & 1 & 4,450 & 1,092 & 0.245 & 11.575 \\
\hline & 23 & 村山 富市 & 1994.06 & 4 & 21,724 & 2,344 & 0.108 & 11.245 \\
\hline & 24 & 橋本 龍太郎 & 1996.01. & 5 & 28,477 & 2,677 & 0.094 & 11.217 \\
\hline & 25 & 小湔 恵三 & 1998.06 & 5 & 21,798 & 2,443 & 0.112 & 11.700 \\
\hline \multirow{8}{*}{ IV. 平成後期 } & 26 & 森 喜朗 & 2000.04 & 4 & 21,374 & 2,350 & 0.110 & 11.366 \\
\hline & 27 & 小泉 純一郎 & 2001.04 & 11 & 49,350 & 3,931 & 0.080 & 12.513 \\
\hline & 28 & 福田 康夫 & 2007.09. & 2 & 10,491 & 1,732 & 0.165 & 11.957 \\
\hline & 29 & 麻生 太郎 & 2008.09 & 2 & 8,223 & 1,742 & 0.212 & 13.584 \\
\hline & 30 & 鳩山 由紀夫 & 2009.09 & 2 & 14,966 & 2,367 & 0.158 & 13.681 \\
\hline & 31 & 菅直人 & 2010.06 & 3 & 15,381 & 2,337 & 0.152 & 13.325 \\
\hline & 32 & 野田 佳彦 & 2011.09. & 4 & 20,583 & 2,800 & 0.136 & 13.800 \\
\hline & 33 & 安倍 晋三 * & 2006.12 & 16 & 77,304 & 5,677 & 0.073 & 14.438 \\
\hline
\end{tabular}

[4] 村井源; 松本斉子; 山本竜大; 徃住彰文:「Web の計量言語学的分析からみた政治的感性の特 徵」. 感性工学研究論文集, Vol.7, No.3, pp. 561-569, 2008.

[5] 鈴木崇史; 影浦峡:「名詞の分布特徴量を用いた 政治テキスト分析」, 行動計量学, Vol.38, No.1, pp. 83-92, 2011.

[6] 田中明彦: データベース「世界と日本」http: //worldjpn.grips.ac.jp/ (2020 年 4 月 10 日参照).

[7] Maron, M. E.: Automatic indexing: An experimental inquery. Jounal of the association for Computing Machinery, Vol.8, No.3, pp. 404-417, 1961.
[8] Carroll, J.B.: On sampling from a lognormal model of word frequency distribution. Computational analysis of present-day American English. pp. 406-424, 1967.

[9] gensim topic modelling for humans: https: //radimrehurek.com/gensim/ (2020 年 4 月 10 日参照).

[10] Röder, M., Andreas, B., and Alexander, H.: Exploring the space of topic coherence measures. Proceedings of the Eighth ACM International Conference on Web Search and Data Mining, pp. 399-408, 2015. 